\title{
Research on the Application Demonstration of Solar Power System for Remote Rural Residences
}

\author{
Jinkun Sun ${ }^{1,2, a}$, Changhong Chen ${ }^{1,2, b}$, Qian Zhang ${ }^{1,2, c}$, Hong Zhuang ${ }^{1,2, d}$ \\ ${ }^{1}$ School of Civil and Architecture Engineering, Panzhihua University, Panzhihua 617000, Sichuan, China \\ ${ }^{2}$ Institute of Engineering Structure, Panzhihua University, Panzhihua 617000, Sichuan, China \\ apaxf66290838@163.com, b864053617 @qq.com, c418677556 @qq.com, d6839951 @qq.com
}

Keywords: Remote rural residence; Solar energy, Photovoltaic system, Energy saving and emission reduction, Demonstration of application

Abstract. This research project applies solar energy photovoltaic power generation system to remote rural residences in order to solve the power consumption problems of the villagers. And this project is the first demonstration project of the application of new energy - solar energy, in the production and life at the rural areas of the city of Panzhihua. Through a series of research on the selection of demonstration sites, the analysis of the conditions of demonstration sites and the design of the solar photovoltaic power generation systems, combining the villagers' residences and the solar power systems effectively, this research elaborates the major issues such as the design principles and the basis of the technology scheme of the $300 \mathrm{~W}$ solar photovoltaic power generation system, the determination of the load power of the users, as well as the determination of power and configuration of power stations and the management of running so as to achieve the balance of researching on the project and benefiting people at the same time. It has improved the living standard and living environment of the farmers in the demonstration sites, and it has provided a positive and beneficial demonstration for the application of solar energy in remote rural residences.

\section{Introduction}

In recent years, issues of infrastructure construction in rural areas such as roads, electricity and communications increasingly attract the attention of the state. Remote rural areas which are limited to the remote and steep terrain and the power grid can hardly cover those areas completely, or the cost is relatively high. It has become a big problem, blocking the realization of basic livelihood projects in rural areas. With the promotion of the solar energy policy and the development of photovoltaic power generation technology in our country, solar photovoltaic power generation system is applied to rural residences to achieve the integration of solar building, which is a very convenient, effective and relatively low-cost measure. It has a positive and practical significance for the realization of the demand of the villagers in remote areas and the improvement of the life quality of the villagers, as well as for narrowing the gap between the rich and the poor. But how to choose and analyze the demonstration sites, how to design the solar photovoltaic power generation systems and how is the economic benefit of energy saving and emission reduction, all these questions are lack of specific cases to refer to. Therefore, the study and practice of this kind of engineering projects will provide valuable demonstrations and references for the application of solar energy on the construction of remote rural areas.

\section{Project Overview}

Solar energy demonstration subproject of Liuxian village, Panzhihua City locates in remote high mountains, being the last three residences in the entire village that have not connected to the power grid and the villagers' lives are extremely inconvenient. The annual average temperature of the implement site of the project is $20.6^{\circ} \mathrm{C}$, the lowest temperature being $-5^{\circ} \mathrm{C}$ and the highest temperature being $41^{\circ} \mathrm{C}$, and throughout the year, the average temperature of the coldest month is $5{ }^{\circ} \mathrm{C}$ and the average temperature of the hottest month is $37^{\circ} \mathrm{C}$, and annual sunshine time is about 2838 hours, 
making here one of the areas that have the best conditions of developing and utilizing solar energy and other public energy-saving designs throughout the country[1]. The project has chosen three Yi peasant households in Liuxi Village with connected courtyards, and the residences are ordinary one-layer adobe houses which are three-in-one courtyard buildings of the Han nationality, and there is a screen wall facing the gate of each house, and the area of the structure is $264 \mathrm{~m}^{2}$, and they are the only residences in Liuxi Village with no electricity. So the project has strong demonstration effects and social effects. This project costs 55,000 yuan in total, and it will play a model leading role in the applying of solar energy when completed, actively responding to the call of energy saving and emissions reduction from the state, and it will achieve the integration of solar buildings. Combined with the structure and the function of the residences, the layout and the installation of the solar energy system is shown in Fig.1.

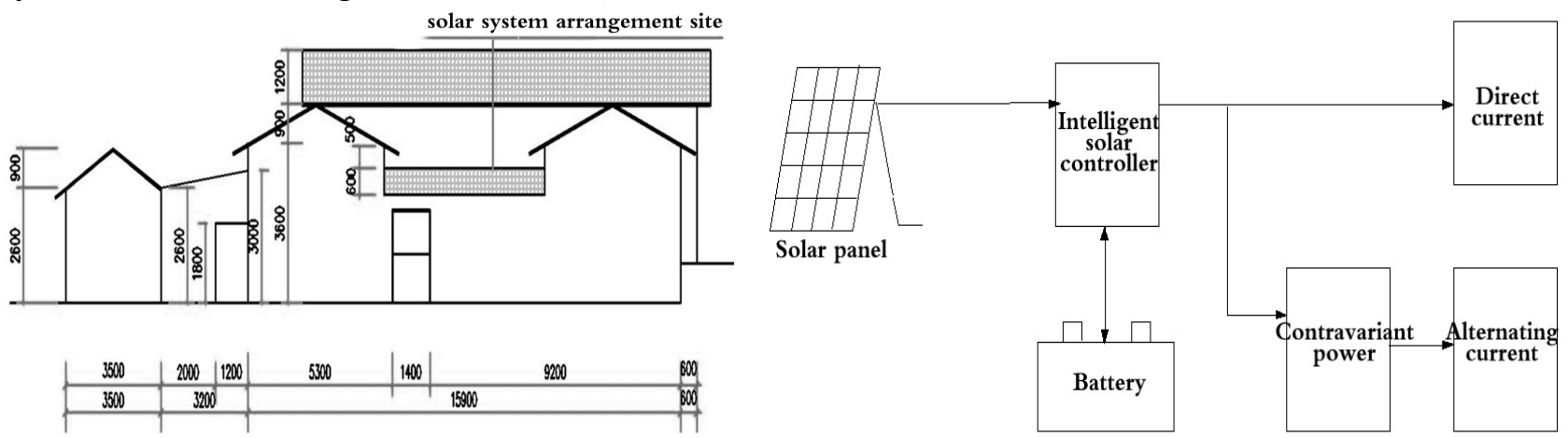

Fig.1 the layout and the installation of the solar energy systems

Fig.2 The sketch map of 300W solar photovoltaic power generation system

\section{The Choice of the Demonstration Sites}

In combination with the reality, the principles of the choosing of the demonstration sites are determined :

- The adaptation of solar energy power supply system, solar-powered building integration or the demonstration of the concentrated application of other solar energy power generating products should be preferentially considered.

- That the solar energy products will have a good demonstration effect after installation should be taken into account, and demonstration sites that are typical and representative should be chosen as far as possible.

- The convenience of designing, installing, data collecting and exhibiting during all the aspects of the implementation of the project should be taken into consideration, and the rural areas with convenient transportation should be chosen as far as possible.

- The constraints of the project funds should be fully considered, and the feasibility and controllability of the late maintenance should also be taken into consideration.

According to the principles above, the specific choices and arrangements are as follows:

Choosing 3 peasant households of the Yi nationality from Liuxi Village, whose courtyards are adjacent to each other and relatively concentrated; The $3 \mathrm{Yi}$ farmers' households chosen in this project are the only farmers who have no access to electricity in Liuxi Village, and the implementation of this project has a strong demonstration effect and social effect; in the implementation process of this project, the newly-built mountain road could just be open to traffic, which perfectly solves problems on material transportation and the traffic inconvenience for viewing and demonstrating in the future; based on the project study, the implementation of this project should reflect the effect of benefiting people, and should raise the living level of local farmers and improve their living environment. Situation Analysis of Exemplary Bases

The analysis of existing conditions of exemplary bases is as below:

There are three families residing in this site and the nationality of them are all the Yi nationality. Their dwelling places are relatively remote in the high mountain with an altitude of more than 2500 
meters and are not connected to the power network; The dwelling places are in high elevation mountain area and a mountain road open to traffic has been built; Their houses have no power supply and are lack of water. They live in great inconvenience, especially at night; Their major economic sources are corn, walnuts and aquaculture and they are in poverty.

The followings are problems need to be solved:

- Interior illumination. Those children who are still going to school would be significantly influenced by the lack of electricity.

- Lack of production electricity. Produced corns need to be broke for the use of breeding industry, and now people have no choice but going to the village to break corns, being far and expensive.

- The outdoor lighting. Because they are in high mountain area, their activities are extremely inconvenient at night.

- Household electricity. As there is no power supply, televisions or radios cannot be used, mobile phones cannot be recharged as well, etc.

- The wood used for cooking and heating comes from forest cutting, which is against protecting environmental resources.

\section{Analysis and Determination of the Technical Scheme}

Designing Principle and Basis. Determine the capacity of solar power generation according to the specific situation and the load power consumption from the field investigation of the solar energy resource in the area of Miyi County, Panzhihua City, Sichuan Province to guarantee the all-year normal power supply for home appliances. The design should be economical, practical and reliable. According to the main indexes for the system, the solar battery modules must be sure to have a long life length for use, not shorter than 20 years for the design; the capacity of the storage battery can fulfill the continual power supply in 3 to 4 cloudy and rainy days when the battery isn't charged by the solar energy; the altering efficiency of the DC/AC inverter is high and it is designed to be $\geq 85 \%$ while the output is $80 \%$ of the rated power. Regular and experimental parameters: the inclination of the solar energy battery matrix is $30^{\circ}$; the solar cell array will receive a radiation quantity 1.1 times of the average value; according to measurement and calculation, the average peak sunshine hours in the Miyi area per day (on the cell array) is 4.5 hours [2].

Determination of User Load Power. According to the users' routine loads, we calculated the daily electricity consumption from the aspects of quantity, power and basic working hours and obtained that the users' load power is $137 \mathrm{~W}$ and the daily electricity consumption is $676 \mathrm{WH}$. Specific data is shown in Table1.

Table1 Statistication of users' equipment installation and load power electricity

\begin{tabular}{ccccc}
\hline Name of load & Power & Number & $\begin{array}{c}\text { Daily working } \\
\text { time }\end{array}$ & $\begin{array}{c}\text { Daily Power } \\
\text { consumption }\end{array}$ \\
\hline 21 "Color TV satellite receiver & $65 \mathrm{~W}$ & 1 & $4 \mathrm{H}$ & $260 \mathrm{WH}$ \\
\hline $11 \mathrm{~W}$ energy-saving lamps & $8 \mathrm{~W}$ & 4 & $8 \mathrm{H}$ & $256 \mathrm{WH}$ \\
\hline satellite receiver & $20 \mathrm{~W}$ & 1 & $4 \mathrm{H}$ & $80 \mathrm{WH}$ \\
\hline Other small home appliance & $20 \mathrm{~W}$ & - & $4 \mathrm{H}$ & $80 \mathrm{WH}$ \\
\hline Total & $137 \mathrm{~W}$ & - & - & $676 \mathrm{WH}$ \\
\hline
\end{tabular}

Determination of Power and Configuration of the Photovoltaic Power System.

Accumulator Pack Capacity Design. The capacity of accumulators is crucial to guaranteeing the continuous power supply. Because the power for the equipment is supplied by the storage battery, the power generated by the solar energy matrix every day should be stored into the storage batteries for the consumption of the equipment, but the solar energy matrix needs to generate more power for storage in the storage batteries for the use on cloudy or rainy days. So the calculation formula of the capacity of storage battery $\mathrm{BC}$ is: 


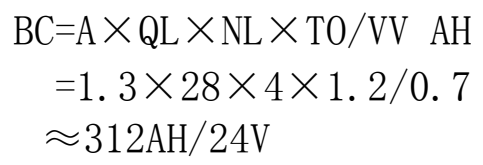

In the formula: $\mathrm{A}$ is factor of safety, taking the value between 1.1 and 1.4; $\mathrm{QL}$ is average power consumption in load day, taking it with working current multiply by day working hours; T0 is the temperature correction coefficient. Generally, it should take the value of 1 above $0{ }^{\circ} \mathrm{C}, 1.1$ above $-10^{\circ} \mathrm{Cand} 1.2$ below $-10^{\circ} \mathrm{C}$; CC is the depth of the square matrix of the accumulator, In general, a lead accumulator should take the value of 0.7 .

The Design of the Solar Battery Square Matrix. Select the basic unit of the solar battery square matrix, and the draft selection of the single unit is $24 \mathrm{~V}$ and the solar cell module is $150 \mathrm{WP}$;

Daily generating capacity of a single unit construction:

Power $\mathrm{x}$ charging time $\mathrm{x}$ comprehensive efficiency of charging $\mathrm{x}$ wear and tear

$=150 \mathrm{WP} \times 4 \mathrm{H} \times 0.7 \times 0.9=378 \mathrm{WH}$;

Daily power consumption:

load daily power consumption/DC/AC efficiency $=676 / 0.85=800 \mathrm{WH}$;

The number of components:

daily power consumption/ single module component daily electricity generation $\times$ margin $=800 \mathrm{WH} / 378 \mathrm{WH} \times 1.2 \approx 2.5$ blocks.

The margin indicates the remaining electricity after solar cell modules' electricity generation meet the loads' daily power consumption. Considering $20 \%$ of the overmeasure of daily solar power generation, that is, the overmeasure of 4 or 5 sunny days, can satisfy the power consumption of a rainy day, or supply enough power for working continuously for four rainy days [3].

Through above analyses and calculation, it can be figured out that demonstration engineering points totally need two 150WP modules, whose total power is 300WP. Finally, the technical scheme of the $300 \mathrm{~W}$ solar photovoltaic power generation system is confirmed.

The Selection of Solar Charge Controllers. Combining with the above calculation and analyses, the microcomputer intelligent charging and discharging controller adopted by the demonstration project meets the design requirement. The controller's input voltage and input current are DC24V and $30 \mathrm{~A}$, and it can be connected to the 500WP solar cell battery to the greatest extent.

The Selection of Inverters. One $0.5 \mathrm{~K}$ sinusoidal inverter is adopted; Pure sine wave output (Distortion rate $<3 \%$ ); output frequency 50/60HZ; complete isolation design for input and output; design of lightning protection for input and output; it can be applied to the display of capacitive and inductive load three-color indicators, input voltage, output voltage, load level and malfunction situations; the load controls the cooling of fans; the advanced microprocessor controls the system design; protection of overvoltage/under voltage/short circuit/overload/over moisture.

In conclusion, the configuration to obtain $300 \mathrm{~W}$ solar photovoltaic power generation system is listed on Table 2.

Table 2 The configuration scheme of $300 \mathrm{~W}$ solar photovoltaic power generation system

\begin{tabular}{cccc}
\hline Device name & Specifications & Number & $\begin{array}{c}\text { Note } \\
\text { (households) }\end{array}$ \\
\hline Solar panels & DC24V 150WP & 2 & 3 \\
\hline $\begin{array}{c}\text { Charge and discharge control } \\
\text { inverter }\end{array}$ & DC24 500W & 1 & 3 \\
\hline 1.2meter-cabinet & $18 \mathrm{U}$ & 1 & 3 \\
\hline battery & DC12V 150AH & 4 & 3 \\
\hline Light line & $3 、 6 、 9 、 15 \mathrm{~m}$ & 1 & 3 \\
\hline AC energy-saving lamps & $8 \mathrm{~W}$ & 4 & 1 \\
\hline Color TV & $21^{\prime \prime}$ & 1 & 1 \\
\hline Satellite receiver & $1.5 \mathrm{~m}$ & 1 & 3 \\
\hline Solar photovoltaic frame & & 1 & \\
\hline
\end{tabular}


Operation Management. There will be some training about the knowledge of using electricity safely and photovoltaic generation to explain how to use the system and matters needing attention for the users. Rules should be formulated and each user is supposed to possess one (regulation for safe use of photovoltaic system), which stipulates that users should use electricity in correct method. Moreover, the uses should not remove the power generation equipment, change the connecting circuit or replace with non-energy saving luminaries [4]. Select one or two literate and responsible persons to manage the system. They should routinely manage and maintain the power generation system, in order to ensure and prolong its operating cycle; meanwhile, they also work as front information statisticians of this exemplary solar project.

Analysis of Energy Saving and Emission Reduction Indexes of the System. We analyze the indexes of yearly achieving energy-saving and emission-reduction of the solar photovoltaic power generator system. The installed capacity of this system is $300 \mathrm{WP}$. When checking according to the average annual sunshine peak hours which is $4 \mathrm{H}$, the annual energy output of the power generator system is $300 \mathrm{WP} \times 4 \mathrm{H} \times 365 \mathrm{D}=438000 \mathrm{WP} \approx 440 \mathrm{KWH}$; The putting into operation of this power-generation system can save equivalent $1400 \mathrm{KG}-2200 \mathrm{KG}$ coal and reduce greenhouse-gas emissions of $4400 \mathrm{KG} \mathrm{CO} 2$ and $130 \mathrm{KG} \mathrm{SO} 2$ every year. The completion of electrical power generating system will play a demonstration leading role for the usage of new energy resources[5] . It responds to the appeal of energy conservation and emission reduction of our country, and has profound social and economic benefits. The sketch map of $300 \mathrm{~W}$ solar photovoltaic power generation system is shown in Fig.2.

\section{Conclusions}

This project combined villagers' houses and solar power systems effectively through the application of the photovoltaic power system in rural houses, realized the purpose of integration of solar systems and buildings and provided life-use electricity for rural residents' production and living in remote areas.

The implementation of this project not only provides useful exploration and practice in the demonstration site selection, demonstration site situation analysis and solar photovoltaic power generation system design and a series of problems, but also uses solar energy to improve the consciousness of environmental protection of villagers.

The whole Liuxian Township has power supply now by this project, which is a historic event. With good technical, economic and social effects, the project is a model of engineering applications for new energy in production and life in the country.

\section{References}

[1] Jun Mao, Weiwei Tang. Solar Energy and Building Integrated Application. [J].Value Engineering. 2010(4) P.93-94[In Chinese].

[2] Jun Mao. The Application in Design and Construction of Solar Photovoltaic Power Generation System [M]. Beijing: People's Posts and Telecommunications Press, 2012[In Chinese].

[3] GB/T 13539.6-2013 Solar Photovoltaic.China Standard Press[M].2013[In Chinese].

[4] Hong Liu.Home Solar Photovoltaic Power System[M]. Beijing: Chemical Industry Press.2007[In Chinese].

[5] Xiao Xiao,Deying Li. Application Status and Development Trend of Solar Photovoltaic

Building Integration[J]. Energy Conservation Materials .2010(2)P.22-24[In Chinese]. 